\title{
The Causes of Epochē: A Note on Stromateis 8.22.1-4
}

The majority of the excerpts traditionally taken to derive from a planned book 8 of Clement of Alexandria's Stromateis concern the theory of demonstration (apodeixis) and related matters of logic. The suspension of judgement (epochē), a recognisably sceptical response to disagreement and a lack of demonstrative certainty, receives two brief treatments in this context. Apart from an attempted refutation of scepticism which points to the allegedly self-refuting character of universal epoche (5.15.2-16.3), the text also includes an account of the causes that lead one to suspend judgement (7.22.1-4).

The source of this treatment of scepticism is unknown. ${ }^{2}$ In his recent edition, translation, and commentary, Matyáš Havrda gives a judicious overview of the scholarly proposals and argues that a liber logicus, perhaps Galen's lost work On Demonstration (De Demonstratione or Peri Apodeixeōs), could have been the direct or indirect source of parts or the whole of the alleged book $8 .^{3}$ At the same time, Havrda is not convinced that this material ever made it into a Clementine book. In his view, it is

1 This paper was presented at a workshop entitled “'Liber Logicus' by Clement of Alexandria: Proof, Inquiry, Scepticism, Causation in an Early Christian Text” held at the Czech Academy of Sciences, Prague, April 20-22, 2017. I thank the DFG-2311 for their financial support and Matyáš Havrda and my anonymous reviewers for comments on an earlier draft.

2 Scholars either cautiously refer to an otherwise unknown liber scepticus, treat the anti-sceptical strategy of the first excerpt as reflecting a Stoic position, or suggest that Clement's source had something to do with Aenesidemus, the most notable sceptical figurehead of his native Alexandria. See Hans von Arnim, De octavo Clementis Stromateorum libro (Rostock: Adler, 1894), 11-15; Christiane von Wedel, Symbola ad Clementis Alexandrini Stromatum l. VIII interpretandum (Berlin: s.n., 1905), 5-8; Eric F. Osborn, The Philosophy of Clement of Alexandria (Cambridge: Cambridge University Press, 1957), 149-51; Karel Janáček, "Ainesidemos und Sextos Empeirikos," in Studien zu Sextus Empiricus, Diogenes Laertius und zur Pyrrhonischen Skepsis, ed. Filip Karfík and Jan Janda (Berlin and New York: De Gruyter, 2008), 251-64 (originally published in Eirene 17 [1980]: 5-16); Karel Janáček, "Zur Interpretation des Photiosabschnittes über Ainesidemos," in Studien zu Sextus Empiricus, Diogenes Laertius und zur Pyrrhonischen Skepsis, 216-24 (originally published in Eirene 14 [1976]: 93100). For the suggestion that the so-called book 8 transmits Antiochean material, perhaps with Peripatetic mediation, see Reginald E. Witt, Albinus and the History of Middle Platonism (Cambridge: Cambridge University Press, 1937), 31-41.

3 Matyáš Havrda, The So-Called Eighth Stromateus by Clement of Alexandria: Early Christian Reception of Greek Scientific Methodology (Leiden and Boston: Brill, 2016), 34-50 (with reservations as to whether the Galenic source would have covered the excerpts on suspension); see also Matyáš Havrda, "Galenus Christianus? The Doctrine of Demonstration in Stromata VIII and the Question of Its Source,” Vigiliae Christianae 65, no. 4 (2011): 368-72. 
unlikely that these excerpts were intended, "at least in the form preserved for us," as another book of the Stromateis. ${ }^{4}$

It goes without saying that theories concerning the text's provenance depend to a large extent on the appreciation of its philosophical content. The excerpts on scepticism are interesting both with regard to the broader question of the text's origin and in their own right. In this paper, I aim to contribute to the analysis of the sceptical ideas contained in the alleged book 8. I offer considerations in favour of the scholarly consensus that the version of scepticism discussed therein is different from, and earlier than, the variant of Pyrrhonism formulated by Sextus Empiricus. ${ }^{5}$ In doing so, I revisit and partially correct some of the received arguments in support of this claim, ${ }^{6}$ so as to place the position on a more solid footing.

First, I will give a brief overview of both the argument from self-refutation employed in the first Clementine excerpt and the Sextan rejection of a related argument. I will argue that the comparison does not support definite claims about the origin of the Clementine material (section 1). Then I will discuss the second excerpt, which offers a series of remarks on the causal origin of epoche (section 2). I will then contrast it to Sextus's account of the origin of suspensive disposition in terms of originative principles (archai) rather than causes (aitiai), arguing that Sextus's formulation allows for a more nuanced sceptical position (section 3). In conclusion, I will briefly consider possible views on the relevance of this material, or the lack thereof, for Clement's Christian project (section 4).

\section{1}

The first excerpt, which appears under the inserted heading Pros tous Pyrrōn[e]ious (using the Byzantine spelling), criticises the sceptical position on two counts. The first objection is that one could hold the statement "nothing is certain" (bebaion einai mēden) to be true only on pain of self-refutation (15.2-7; cf. 16.1). This is then followed by the claim that one cannot even begin to inquire without a previous apprehension of some states of affairs, which in turn implies that something certain can be apprehended (15.7-9). ${ }^{7}$

4 Havrda, So-Called Eighth Stromateus, 10, cf. 14, 25, 50. Nevertheless, he entertains the possibility that while composing book 7, Clement made use of something like the so-called book 8 (70, cf. 74). For his summary statement, see 76-77.

5 See Janáček, “Ainesidemos und Sextos Empeirikos,” 252-54; Havrda, The So-Called Eighth Stromateus, 244 n. 299.

6 Janáček's main argument for a non-Sextan variety of scepticism is puzzling at best; see my discussion of T4 below.

7 For Sextus's claim that the sceptic can act and investigate without dogmatic apprehension, see his distinctions between two senses of dogma ( $P H$ 1.13) and two senses of katalepsis ( $P H$ 2.1-11). 
More precisely, the charge of self-refutation is introduced in book 8 as one horn of a dilemma. In response to the question of whether anything is true, one might either give an affirmative answer, which amounts to a rejection of the claim that "nothing is certain," or hold that nothing is true, which turns out to be a self-refuting position. Similar objections were routinely raised about a variety of sceptical positions. ${ }^{8}$ A version of the objection is addressed by Sextus Empiricus, who states that utterances such as "everything is false" (panta esti pseude) or "nothing is true" (ouden estin alèthes) apply to themselves and cancel themselves out (symperigraphei, $P H$ 1.14). Sextus gives a variety of responses in the Outlines $(P H 1.14,206 ; 2.188$, all three passages featuring the term symperigraphein; cf. also $P H 2.84)$, as well as in the second book of Against the Logicians ( $M$ 8.55, 480-81).

According to the received view, Sextus's main strategy is to embrace the self-refuting nature of self-referring sceptical utterances. ${ }^{9}$ According to a recently proposed alternative view, however, the term symperigraphein invokes a specifically Pyrrhonian strategy which was designed to avoid self-refutation. On this proposal, self-referring utterances are self-refuting only if and when they are advanced with a dogmatic mindset; i.e., when the premises and the conclusion are endorsed as true by the one who utters or entertains them. By contrast, when uttered or entertained with a suspensive disposition already in place, they "bracket themselves" (this being the proposed translation of symperigraphein), as a result of which no contradiction arises. ${ }^{10}$

On either reading, Sextus is ready with an answer to the sort of objection from self-refutation that we find endorsed in the first of the two excerpts from book 8 . On the novel reading, however, it becomes possible to claim that the sceptical response that Sextus preserved is reported under Clement's name as well. One of two occurrences of the key term in Clement comes "seemingly with the same meaning as in Sextus and in a sceptical context."11 One could suggest on this basis that the two texts show little difference in terms of philosophical sophistication. Furthermore, even if we discount this possibility and admit that the source informing the Clementine passages is philosophically less advanced than Sextus, it might still not suffice to establish a chronological difference. After all, individuals working at the same time and place might achieve different levels of philosophical acuity. ${ }^{12}$

8 For similar objections, see Cicero, Acad. 2.29, 109; Aristocles apud Eusebius, Praep. evang. 14.18.524; Photius, Bibl. 212.169b.18-31; Sextus Empiricus, M 7.399, 440; 8.55; cf. already Aristotle, Metaph. 4. 8.1012b13-22.

9 See especially Mark L. McPherran, "Skeptical Homeopathy and Self-Refutation," Phronesis 32 (1987): 290-328.

10 Luca Castagnoli, Ancient Self-Refutation: The Logic and History of the Self-Refutation Argument from Democritus to Augustine (Cambridge: Cambridge University Press, 2010), 251-307, especially 266, 269, 277.

11 Castagnoli, 351 n. 137, pointing to 8.22.2 (T4 below). The other Clementine passage, Strom. 6.15.119.4, is irrelevant for, and impossible to square with, Castagnoli's interpretation.

12 It is worth mentioning that if these passages had indeed been derived from Galen, then one could even come to imagine-though not in any way to establish-that Sextus was responding to the sort of 
Nor does it follow that the second excerpt, a causal account of the origins of epoche which does not even mention the argument from self-refutation, represents a less developed form of scepticism. With these reservations in mind, I will now turn to the causal account developed in the second excerpt.

\section{2}

Even though the first excerpt rejects universal epochē, it does allow for the legitimacy of suspending one's judgement on particular occasions:

[T1] Not only the "suspenders," but every "dogmatist" too is used to suspending judgement in some matters, either from weakness of thought, [or from] the obscurity of things, [or from] the equipollence of arguments (16.3). ${ }^{13}$

The second excerpt arguably picks up on the conciliatory tone of this remark and goes on to explain the reasons for widespread disagreement in the domains of inquiry and ordinary life. It is, of course, questionable whether these two discussions derive from the same source or even express the same generic outlook concerning scepticism. At any rate, even if it is possible to detect a transition from a distinctly antisceptical perspective to another which is mildly sympathetic to sceptical considerations, ${ }^{14}$ the crucial link seems to be provided by the observation that localised epoche is a common resort of both sceptics and doctrinaire philosophers.

On the account at hand, there seem to be three reasons why one might suspend one's judgement. The first has to do with a subjective condition; namely, the weakness or infirmity of one's own cognitive capacities. By contrast, the second reason has to do with the objects of inquiry: they are unclear or obscure, and hence they do not deliver immediate knowledge of themselves. Finally, the arguments one might consider for and against accepting a given proposition are said to be equipollent. Going only by this brief sentence, it is unclear how these three sources of suspension are supposed to relate to each other.

The second excerpt is almost entirely devoted to the discussion of the causes (aitiai) of the suspension of judgement. To begin with, it states:

anti-sceptical considerations that Galen had put forward. Unfortunately, the limits of historical fancy are set by the available evidence, and nothing seems to support such a connection.

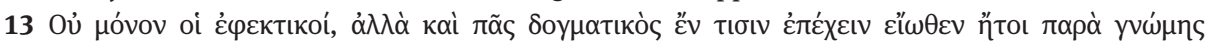

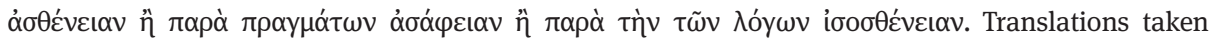
from Havrda, So-Called Eighth Stromateus.

14 "This excerpt or paraphrase [i.e., the second] was probably made by the same author who accepts the limited validity of epoche in 16,3 , not in order to embrace scepticism, but rather to represent the sceptic's position with his [i.e., the sceptic's] own words" (Havrda, 241). 
[T2] The most general causes of suspension of judgement are two. One is the fickleness and instability of the human mind; it naturally generates disagreement, either that of one with another, or that of one with oneself. Second is the disagreement in things, which also, with good reason, comes down to inducing suspension of judgement $(22.1=93.19-23) .{ }^{15}$

This passage differs from T1 in a number of respects. First, it leaves out the equipollence of arguments mentioned above. Second, it explicitly casts the other two sources of epoche in causal terms. In addition, it seems that equipollence is here replaced by disagreement (diaphōnia), which figures twice in T2. On the one hand, it is a consequence of the fallibility of the human mind, which, by its nature (note the term gennetikon, which will reappear in $\mathbf{T} 3$ below), brings about a variety of differing opinions on both the interpersonal and the intrapersonal level. On the other hand, disagreement applies to the nature of things themselves (hē en tois ousi diaphōnia), perhaps in the sense that they give rise to anomalous appearances. ${ }^{16}$

The final, lengthiest discussion of the causes of epoche gives yet another variation on the same theme. According to the passage below, which includes a vivid description of the dogmatic predicament, disagreement is the proximate cause of suspension of judgement (hè de diaphōnia proseches aition tēs epochēs), and it is ultimately due to the condition of the human mind, with no explicit mention of the nature of things themselves:

[T3] Out of these most principal [causes] of suspension, the infirmity of the mind is the one that generates disagreement, and disagreement is the proximate cause of the suspension of judgement. As a consequence, life is full of courts, councils, assemblies, and, generally speaking, choice <and avoidance> regarding so-called good and evil things. These are tokens [showing] that the mind is puzzled and that it wavers vis-à-vis the equipollence of opposing things. And libraries are full of books of people disagreeing with one another in their beliefs, each having convinced himself that he knows the truth in things $(22.3-4=93.27-94.4){ }^{17}$

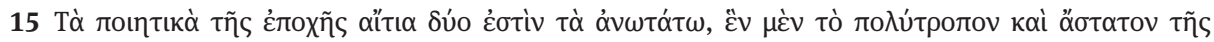

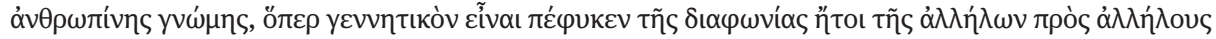

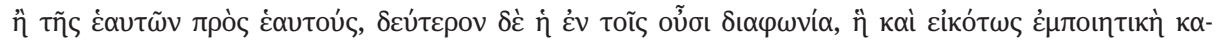

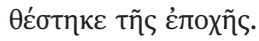

16 But cf. von Wedel's alternative classification: "Et eodem modo bipartitae sunt causae غ̇лохп̃

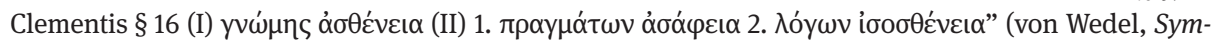
bola ab Clementis Alexandrini, 8). My understanding is closer to the contrast in Osborn, The Philosophy of Clement of Alexandria, 151 (on the one hand, people change their minds and disagree with each other; on the other hand, the world as such presents us with conflicting appearances).

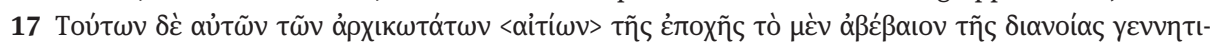

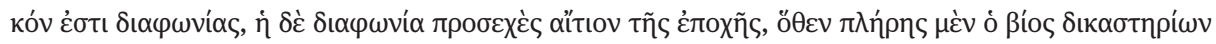

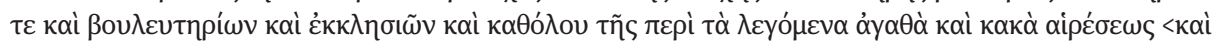

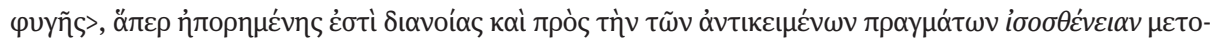

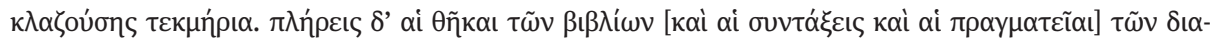

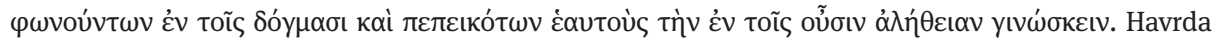

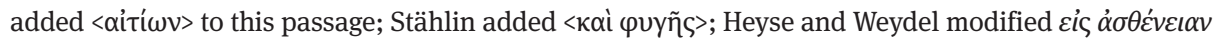

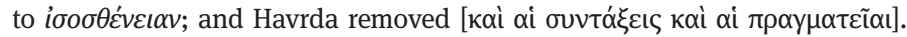


Whether or not one is sympathetic to the assumption that all three passages (T1-T3) belong to one and the same account concerning the causes of suspension, one might find the last version to be the closest to Sextus Empiricus's Pyrrhonian stance. After all, in T3, the major consideration in favour of epoche appears to be equipollence. On the one hand, there is widespread disagreement in matters of theory and practice; on the other, contrary arguments turn out to be equally persuasive, and this is in fact the main feature that defines Sextan scepticism ( $P H$ 1.8). Insofar as this passage downplays or drops the idea that disagreement is due to the nature of the things investigated, it might after all manage to escape a lurking dogmatic commitment concerning the objective limitations of our capacity for knowledge. ${ }^{18}$

Nevertheless, the emphasis on our subjective limitations might still hold the danger of latent dogmatism. In this respect, it is not so much the characterisation of the human mind as feeble or changeable (polytropos and astatos in T2; abebaios in T3) which seems problematic, but rather the claim that it is a congenital condition. ${ }^{19}$ If equipollence is merely a consequence of the infirmity of the human mind, the question once again becomes whether this infirmity is due to our limited cognitive capacities or rather to the nature of things themselves. In order to read T3 as obeying the spirit or perhaps even the letter of Sextan Pyrrhonism, this aspect of the account should be downplayed.

The following two considerations indicate a harmonious rapport between Sextan Pyrrhonism and the sceptical stance reported by Clement. Firstly, Sextus's classification of the Ten Modes for epochē shows affinity with the causes specified by Clement: as Sextus puts it, some of the modes have to do with the one who judges, some with the thing being judged, and some with a combination of both (PH 1.38). ${ }^{20}$ The same

18 On the other hand, this might be nothing more than a change of terminology. Perhaps the disagreement en tois ousi amounts to what Sextus calls "anomalies” or conflicting appearances. See, e.g., Sextus's references to anōmalia in his narratives of sceptical conversion ( $P H 1.12,29,214 ; M 1.6)$, as well as throughout his description of the Ten Modes of Aenesidemus ( $P H 1.112,114,132,163,198,218$, 220; cf. 3.233-35, $M$ 9.191, and $M$ 1.154, 236, 240). See also DL 9.76: "Whenever things are at odds with each other and arguments have equal strength, ignorance of the truth follows suit” ( $\tau \tilde{\omega} v \mu \dot{\varepsilon} v$ yò $\rho$

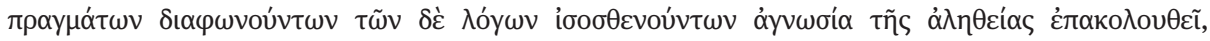
trans. Scharffenberger and Vogt).

19 Interestingly, a related remark from Sextus appears in the context of defending Pyrrhonism against self-refutation by invoking the idea that the human mind will not put lasting trust in the argument against the possibility of demonstration: "However, if the skeptics have to answer for themselves, they will answer in a safe way. For they will say that the argument against demonstration is merely persuasive, and that for the moment it persuades them and induces assent, but that they do not know whether it will also be like this in the future given the fickle character of

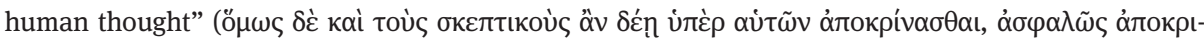

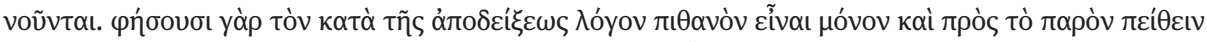

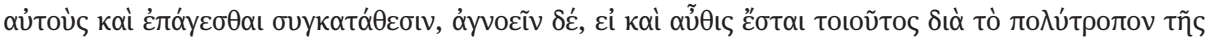

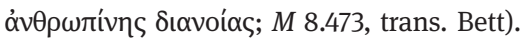

20 "Superordinate to these [i.e., to the Ten Modes] are three modes: that deriving from the subject

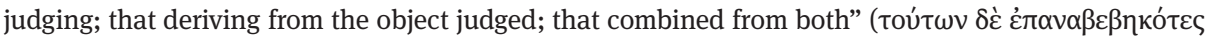


classificatory concern explains his presentation not only of the Ten Modes, but also that of the Five Modes, the Two Modes, and the Eight Modes ( $P H$ 1.31-186). Secondly, an additional argument offered in-between T2 and T3 sounds especially close to a statement of Sextus's official position:

[T4] We can neither believe all presentations, because of their conflict; nor disbelieve them all, because the one saying that all [presentations] are untrustworthy, is bracketed along with the "all," being one of them; nor can we believe some and disbelieve others, because of their equality; thus we are brought to suspension of judgement $(22.2=93.23-27) .{ }^{21}$

Surprisingly, Janáček invokes this passage as the main argument in favour of a preSextan variety of scepticism informing the so-called book 8's treatment of scepticism. ${ }^{22}$ Admittedly, the argument itself has a pre-Sextan pedigree, but there is no reason to believe that it might not form part of a position sufficiently similar to that of Sextus. He himself found it congenial to his presentation of the Pyrrhonist position, as evidenced primarily by his discussion of the criterion of truth, which, at $M 7.389$, starts out with exactly the same sort of argumentation. As things stand, therefore, we find little in book 8's presentation of scepticism which cannot, at the end of the day, be made to square with Sextus's flexible Pyrrhonism.

\section{3}

I have argued thus far that there is a more or less straightforward, if somewhat overzealous, way of reading Clement's account as pointing away from a sceptical view based on dogmatic commitments concerning the nature of reality and towards one that lives up to the Sextan gold standard. My purpose in pushing for such a reading was not to argue that the Clementine excerpts do in fact understand scepticism in the vein of Sextus Empiricus; rather, my intention was to prepare the ground for the next step, which is to draw attention to a more significant difference between these presentations. Quite importantly, while Clement or his source gives a causal account of the suspension of judgement, Sextus embeds his own account in a biographical narrative concerning the conversion to scepticism-not least because a causal account, by his standards, would qualify as dogmatic.

In his idealised biography of an individual who sets out to discover the truth but ends up suspending judgement instead ( $P H$ 1.12, 26, 29), Sextus speaks not of causes

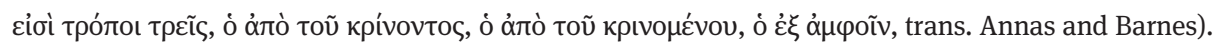
See Havrda, So-Called Eighth Stromateus, 241-42.

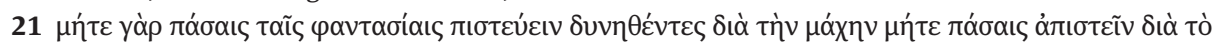

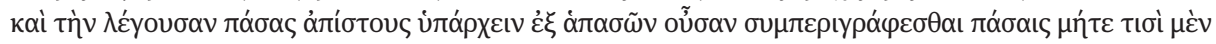

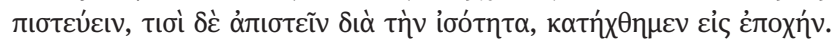

22 Janáček, "Ainesidemos und Sextos Empeirikos," 253: "Das Hauptargument aber für eine ältere skeptische Quelle als Sextos im Klemensabschnitt ist die dreifache Begründung des Skeptizismus." 
(aitiai), but rather of originating principles (archai) which motivate the adoption of a suspensive disposition. Sextus's story describes the interplay of two such principles. The first, originative principle ( $\operatorname{arche}$ aitiōdēs) is the hope of tranquillity: individuals sensitive to philosophical concerns and troubled by their inability to decide between conflicting appearances set out to discover what is true and what is false, in the hope of achieving intellectual tranquillity. The second sustaining or constitutive principle (archē systaseōs) appeals to their eventual recognition that to every account an equally persuasive account is opposed, which leads them to suspend their judgement and, in turn, to a fortuitous state of tranquillity. Since the first principle applies to all philosophers (labeled by Sextus hoi megalophyeis) while the second only applies to those who have become Pyrrhonians, Sextus's narrative links together these two groups in a way that enables him to claim that sceptics are, as their chosen denomination suggests, proper inquirers. ${ }^{23}$

Sextus not only distances himself from the all-too-formal accounts of what brings about epochē; he also manages to establish a continuity between what he takes to be the original motivation for inquiry and the aim of the full-fledged Pyrrhonist. By contrast, book 8 does not engage in conjectures concerning the background of a philosophical sceptic-it does not mention tranquillity or, for that matter, any other possible motivation for adopting a sceptical position. ${ }^{24}$ Nor does it present sceptics as genuine inquirers; rather, the opening passage of book 8 suggests that the sceptical predilection for an aporetic outcome is nothing but an obstacle to genuine inquiry. Insofar as neither of these characteristic features of Sextan Pyrrhonism make an appearance in it, book 8 can hardly be taken to expound a form of scepticism sufficiently similar to that of Sextus.

At this point, one might pose the question why, given such an unflattering view of scepticism, Clement would show any interest in it. If book 8's discussion of scepticism is in fact compatible with Clement's Christian agenda, then the guiding idea must perhaps be that genuine inquiry takes its departure from divine authority, and the alternative to accepting that authority is to engage in the fruitless, sophistical bickering of scepticism. Whether or not this was in fact Clement's position, as we shall see in the concluding section, is ultimately unclear.

\section{4}

Scholars have understandably found it puzzling that a Christian theologian of Clement's standing would express interest in sceptical arguments, let alone recognise

23 For a detailed defence of this reading, see Máté Veres, "Keep Calm and Carry On: Sextus Empiricus on the Origins of Pyrrhonism," History of Philosophy and Logical Analysis 23, no. 1 (2020), special issue on Ancient Modes of Philosophical Inquiry, ed. Jens Kristian Larsen and Philipp Steinkrüger. 24 It has been suggested to me that this might indicate an Aenesideman source, but it is difficult to square this suggestion with $D L$ 9.108; cf. also Aristocles apud Eusebius, Praep. evang. 14.18.2-4. 
their potential legitimacy. ${ }^{25}$ On the basis of the discussion in the previous sections, two possibilities seem to emerge: either to find a place for these excerpts in Clement's Christian thought or to discard them as inauthentic, meta-Stromatic material that bears no relation to it.

As to the former option, one might say that it is not unheard of that a Christian thinker would employ scepticism in support of their religious stance. In such a view, the sceptical predicament shows that human reason naturally generates disagreement, which, if unaided by divine revelation, it cannot ever hope to overcome. ${ }^{26}$ It is conceivable that sceptical argumentation could play an inadvertent role in the formulation of such a quasi-fideistic position: by calling into question our ability to acquire demonstrative knowledge, scepticism can be seen as giving support to revealed starting points for inquiry. ${ }^{27}$

A general context of this sort may bring us closer to appreciating Clement's interest in the book 8 material. Such a reading, then, is at the very least possible; the question is whether there is a textual basis to support it. One might point to the opening paragraphs of book 8, where Clement contrasts more recent Greek philosophers, who reduced themselves to elenctic and eristic argumentation, with both the more ancient Greek philosophers and the true philosophy of those who are led to

25 See Janáček, "Ainesidemos und Sextos Empeirikos," 252: "It [i.e., the second excerpt] is clearly an excerpt from a sceptical author, just as the polemic in III 89-90 [i.e., the first excerpt] betrays an antisceptical author. One could hardly claim that Clement the Christian, an admirer of Plato, Pythagoras, the Stoics, was a sceptic." ("Es ist natürlich ein Exzerpt aus einem skeptischen Autor, gerade wie das Pamphlet III 89-90 einen antiskeptischen Autor verrät. Den Christen Klemens, einen Bewunderer von Platon, Pythagoras, den Stoikern, könnte man mit Mühe einen Skeptiker nennen.”)

26 On the Christian use of sceptical arguments, see Gábor Kendeffy, Az egyházatyák és a szkepticizmus (Budapest: Áron, 1999), especially 48-60. On Clement, see George Boys-Stones, Post-Hellenistic Philosophy: A Study of Its Development from the Stoics to Origen (Oxford: Oxford University Press, 2001), 188-94, and George Karamanolis, The Philosophy of Early Christianity (Durham: Acumen, 2013), 120-27. For a classic statement of such a reading, see Eugène De Faye, "The Influence of Greek Scepticism on Greek and Christian Thought in the First and Second Centuries," Hibbert Journal 22 (1924): 717-20, who argues that the structure and style of the entire Stromateis is ultimately due to Clement being shaken by the force of sceptical arguments. On Clement's project in general, see also Pierre Nautin, "La fin des Stromates et les Hypotyposes de Clément d'Alexandrie," Vigiliae Christianae 30, no. 4 (1976): 268-302, Silke-Petra Bergjan, "Logic and Theology in Clement of Alexandria. The Purpose of the $8^{\text {th }}$ Book of the Stromata," Zeitschrift für Antikes Christentum 12, no. 3 (2008): 394411, and Matyáš Havrda, “Clement's Exegetical Interests in Stromateis VIII," in Clement's Biblical Exegesis, ed. Veronika V. Černušková, Judith L. Kovacs, and Jana Plátová (Leiden and Boston: Brill, 2016), 162-78.

27 For a recent argument that fideism as a distinct philosophical stance appeared in the Alexandrian context as a combination of Jewish monotheism and Aenesideman scepticism in the works of Philo of Alexandria, see Carlos Lévy, "De l'epochè sceptique à l'epochè transcendantale: Philon d'Alexandrie fondateur du fidéisme," in Scepticisme et religion: Constantes et évolutions, de la philosophie hellénistique à la philosophie médiévale, ed. Anne-Isabelle Bouton-Touboulic and Carlos Lévy (Turnhout: Brepols, 2016), 57-73. 
investigation by Scripture (8.1.1). ${ }^{28}$ This might also fit well with Clement's project of carving out a niche for a Christian stance which does not reject philosophical inquiry, but ties its possibility and eventual success to the prior acceptance of Christian revelation. After all, book 8 opens with the interpretation of a biblical passage, Matthew 7.7: "Seek and you will find, knock and it will open, ask and it will be given for you."29

The other option, that scepticism is of little relevance to Clement's stated purposes in the Stromateis, nevertheless remains equally plausible. The closest Clement comes to engaging with sceptical strategies is probably his discussion of the argument from disagreement in book 7 (7.89-90). ${ }^{30}$ In that context, he appears adamant that his method of scriptural interpretation leads to a sort of demonstrative knowledge which is not vulnerable to the challenge of diaphonia. This, of course, could still be squared with the quasi-fideistic suggestion that, if it were not for Scripture, one would never be able to reason one's way out of disagreement; the emphasis, however, is very much on the message of success, not on the appeal of scepticism. ${ }^{31}$

In sum, the questions concerning the origin of these excerpts and their connection to the main text of the Stromateis are at the very least contentious, and suggestions concerning the Clementine appropriation of scepticism for Christian purposes will inevitably stand on shaky grounds. ${ }^{32}$ Hence the modest aim of this paper was to provide an analysis of the causal account of suspension offered in the alleged book 8 and to compare it with the mature Pyrrhonist position of Sextus Empiricus. A more ambitious discussion could venture to situate the Clementine material in its supposedly Alexandrian context and to analyse its possible ties not only to Clement's epistemology and theory of faith, but also to the pre-Sextan form of scepticism reported by Philo of Alexandria and championed by Aenesidemus. ${ }^{33}$ This, however, remains a task for another day.

28 Cf. Stromateis 7.4 and Nautin, "La fin des Stromates," 291. Bergjan, "Logic and Theology in Clement of Alexandria," 406-9, suggests that the proponents of universal suspension of judgement that Clement has in mind are not so much sceptical philosophers, but rather the followers of Tertullian, who reject the religious relevance of rational argumentation.

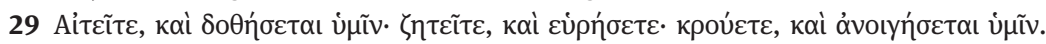

30 For his rather limited awareness of sceptics, see also references to Pyrrho in Stromateis 1.14, 64.4 and 7.16, 101.4 .

31 See Matyáš Havrda, "Demonstrative Method in Stromateis VII: Context, Principles, and Purpose." In The Seventh Book of the Stromateis: Proceedings of the Colloquium on Clement of Alexandria (Olomouc, 21-23, 2010), edited by Matyáš Havrda, V. Hušek, and J. Plátová (Vigiliae Christianae Supplements 117) (Leiden: Brill, 2012), 261-75. Havrda argues that "the material in the eighth book [...] seems to reflect Clement's theological goals to a limited extent only" (263; cf. 270-71).

32 See Havrda, So-Called Eighth Stromateus, 54-55; cf. 27-28 for the claim that only the first chapter of book 8 is of an undoubtedly Christian character.

33 Havrda, 241, points out that other than Clement, only Philo, Ebr. 170-71 speaks of the causes of disagreement and suspension. 


\section{Bibliography}

Arnim, Hans von. De octavo Clementis Stromateorum libro. Rostock: Adler, 1894.

Bergjan, Silke-Petra. "Logic and Theology in Clement of Alexandria. The Purpose of the $8^{\text {th }}$ Book of the Stromata." Zeitschrift für Antikes Christentum 12, no. 3 (2008): 394-411.

Boys-Stones, George. Post-Hellenistic Philosophy: A Study of Its Development from the Stoics to Origen. Oxford: Oxford University Press, 2001.

Castagnoli, Luca. Ancient Self-Refutation: The Logic and History of the Self-Refutation Argument from Democritus to Augustine. Cambridge: Cambridge University Press, 2010.

De Faye, Eugène. "The Influence of Greek Scepticism on Greek and Christian Thought in the First and Second Centuries." Hibbert Journal 22 (1924): 702-21.

Diogenes Laertius. "Lives of Pyrrho and Timon (9.61-116)." Translated by Elisabeth Scharffenberger and Katja Maria Vogt. In Pyrrhonian Skepticism in Diogenes Laertius: Introduction, Text, Translation and Interpretive Essays, edited by Katja Maria Vogt, 16-51. Tübingen: Mohr Siebeck, 2015.

Havrda, Matyáš. "Clement's Exegetical Interests in Stromateis VIII.” In Clement's Biblical Exegesis, edited by Veronika V. Černušková, Judith L. Kovacs, and Jana Plátová, 162-78. Leiden and Boston: Brill, 2016.

Havrda, Matyáš. "Demonstrative Method in Stromateis VII: Context, Principles, and Purpose." In The Seventh Book of the Stromateis: Proceedings of the Colloquium on Clement of Alexandria (Olomouc, 21-23, 2010), edited by Matyáš Havrda, V. Hušek, and J. Plátová (Vigiliae Christianae Supplements 117), 261-75. Leiden: Brill, 2012.

Havrda, Matyáš. "Galenus Christianus? The Doctrine of Demonstration in Stromata VIII and the Question of Its Source." Vigiliae Christianae 65, no. 4 (2011): 343-75.

Havrda, Matyáš. The So-Called Eighth Stromateus by Clement of Alexandria: Early Christian Reception of Greek Scientific Methodology. Leiden and Boston: Brill, 2016.

Janáček, Karel. "Ainesidemos und Sextos Empeirikos." In Studien zu Sextus Empiricus, Diogenes Laertius und zur Pyrrhonischen Skepsis, edited by Filip Karfík and Jan Janda, 251-64. Berlin and New York: De Gruyter, 2008. Originally published in Eirene 17 (1980): 5-16.

Janáček, Karel. "Zur Interpretation des Photiosabschnittes über Ainesidemos." In Studien zu Sextus Empiricus, Diogenes Laertius und zur Pyrrhonischen Skepsis, edited by Filip Karfík and Jan Janda, 216-24. Berlin and New York: De Gruyter, 2008. Originally published in Eirene 14 (1976): 93-100.

Karamanolis, George. The Philosophy of Early Christianity. Durham: Acumen, 2013.

Kendeffy, Gábor. Az egyházatyák és a szkepticizmus. Budapest: Áron, 1999.

Lévy, Carlos. "De l'epochè sceptique à l'epochè transcendantale: Philon d'Alexandrie fondateur du fidéisme." In Scepticisme et religion: Constantes et évolutions, de la philosophie hellénistique à la philosophie médiévale, edited by Anne-Isabelle Bouton-Touboulic and Carlos Lévy, 57-73. Turnhout: Brepols, 2016.

McPherran, Mark L. "Skeptical Homeopathy and Self-Refutation." Phronesis 32 (1987): 290-328.

Nautin, Pierre. "La fin des Stromates et les Hypotyposes de Clément d'Alexandrie." Vigiliae Christianae 30, no. 4 (1976): 268-302.

Osborn, Eric F. The Philosophy of Clement of Alexandria. Cambridge: Cambridge University Press, 1957.

Sextus Empiricus, Against the Logicians. Translated by Richard Bett. Cambridge: Cambridge University Press, 2005.

Sextus Empiricus, Outlines of Scepticism. Translated by Julia Annas and Jonathan Barnes. Cambridge: Cambridge University Press, 2000. 
Veres, Máté. "Keep Calm and Carry On: Sextus Empiricus on the Origins of Pyrrhonism." History of Philosophy and Logical Analysis 23, no. 1 (2020). Special issue on Ancient Modes of Philosophical Inquiry, edited by Jens Kristian Larsen and Philipp Steinkrüger.

Wedel, Christiane von. Symbola ad Clementis Alexandrini Stromatum I. VIII interpretandum. Berlin: s.n., 1905.

Witt, Reginald E. Albinus and the History of Middle Platonism. Cambridge: Cambridge University Press, 1937. 